\title{
Histories and Historians in Israel \& Palestine
}

\section{Transforming Cultures eJ ournal, \\ Vol. 1 No. 1, March 2006 http:// epress.lib.uts.edu.au/journals/TfC}

\author{
Dr Ilan Pappe \\ School of Political Sciences at Haifa University
}

One of the most obvious reasons why historians — both professional and academic find it difficult to challenge hegemonic narratives is psychological. No one wants to be a pariah in their own society by running against the mainstream and finding themselves in an isolated position. But I think there's a deeper level as to why historians have found it so difficult (maybe unlike some of their colleagues in the social sciences), to provide narratives which challenge those which dominate their society's media, culture and academia. And that reason, I think, is that challenging historiographical mythology is not just about facts, it is also about rethinking the role of the historian. It is about being able to update oneself on developments in historiography and even (which is perhaps more difficult for historians), in philosophy. This focuses the question on what is reality, what is fiction, what is myth, and what is a fact. I found that one of the most challenging tasks in dealing with the history of my own country, both for Jewish and Palestinian historians, was not just to provide a different narrative to the one that prevails, but also to be able to tie in concrete discussion with a more epistemological understanding of what history is and how history is received by the public at large.

There was a conference in Florence many years ago in which I gave a paper about construction of national historiographies. I argued that there were differences in the way historians worked in, what I termed, 'relaxed societies' or in 'tense societies'. I thought that in tense societies, where people were writing on an ongoing conflict, the histories of that conflict would be unable, and shouldn't be encouraged, to deal too deeply with more theoretical questions about the nature of reality and history. One might expect the historians in more relaxed societies to do the job for us. But I realised I was wrong: it really depended on the conditions in which you find yourself, rather than the state of the society. I found quite a lot of tense historians in relaxed societies and I regard myself to be a very relaxed historian in a very tense society. 
I want to use two anecdotes which will show that I think the dialectical connection between the general epistemological debates - about what is truth, what is objectivity, what is subjectivity in history - and a more concrete search into the past, is far more complex than people sometimes think. In 1997 in the village of Isawia, which is just adjacent to the Hebrew University's campus on Mount Scopus in Jerusalem, I founded with a friend of mine, Jemil Hillad, a group which was called The Palestinian Israeli Academic Dialogue. It had also a different name, we first called it The Bridging Narrative Group, and the idea was to bring together Israeli and Palestinian historians to construct jointly a narrative for the country.

I was asked to open it with an inaugural speech to the group in which I would talk about historiography, philosophy and national narratives. I started by arguing that any such attempt to bridge narrative between historians of two conflicting national groups has to adopt at least a 'soft' relativist approach to the writing of history, which annoyed both my Palestinian and my Jewish colleagues. Most of them are empiricist and positivist historians, who really believe that all you need is the documents and then you can really reconstruct the past. For them von Ranke's ideas are still very much the dominating guideline.

While I was using the German philosopher Hans-Georg Gadamer to show the connection between hermeneutics and history, the connection between understanding a text and an historical event, we heard the clatter of machine guns next to the house where we had our meeting. I should say we met in a private house because no university, either Israeli or Palestinian, would host a group of Israeli and Palestinians who wanted to construct a joint narrative rather than provide scaffolding for the national narrative. The soldiers burst into the meeting because they were looking for one of our historians, one of our Palestinian historians, and they took him out. And in that moment I lost all motivation to talk about Gadamer and I became a very positivist historian.

A year later, in Paris, the late Edward Said convened a meeting. On the basis of the idea of that bridging narrative group, I had convinced him to convene a meeting between Israeli and Palestinian historians which was sponsored by Le Monde and held in the Hall of the French Senate, which hosts 1,000 people. It was a huge meeting, to our great surprise - or maybe it was because we had Daniel Barenboim sitting in the first row, not 
understanding at all what we are talking about, but his very presence there probably brought a lot of other people thinking he would provide a piano recital at the end. We discussed again the question of history and historiography. The main speaker there was my colleague Benny Morris who claimed that the only way of understanding what happened in Palestine was to use the Israeli military archives because they were the only reliable source of the history of Palestine. That triggered, to my great pleasure, a response by Said about which I don't think he has written anywhere, unfortunately. So it is solely in my memory although I hope that one day I will find the tape of it, as it really should be produced in writing. Said explained to Morris, and I think to the public at large, why an historical document in the military archives is also an interpretation of reality, especially if it had been written by an Israeli officer writing about events in a certain village. Additionally he said, "One wonders about historians who write about the tragedy of another people without any empathy for that tragedy. Can we really then say that their books, like Morris's book about the birth of the refugee problem, are not flawed, just by fact that they have been written by someone who had no sympathy for the tragedy or catastrophe about which they were writing”.

And I think between the two events in Isawia and in Paris, this dialectical connection between how one should relate to history as part of a political project, not just as part of a professional project, is really something that would trouble both Israeli and Palestinian historians. I would like to suggest several guidelines for such a project in the future and also highlight some of the difficulties which should be associated with such a project. Because I think that it redefines, at least where I come from, the role of professional historians. In our system, both in Israel and in Palestine where most universities are public and not private, historians are financed by the state itself or by, in the case of the Palestinian, by the Palestinian Authority itself. How far can we go in challenging the kind of narrative that our financers expect us to produce? What is our role towards our society? I think that my first guideline is that we have to be very wary and apprehensive about taking a very positivist point of view about historiography. In other words, if we claim to be purely scientific researchers, objective, unbiased and we produce narratives that either serve our masters or irritate them; we would lose credibility in the eyes of the public. Obviously this situation would produce a narrative that challenges our master's voice and then there are already two narratives. And what are we going to tell our public? That because we are good scientific researchers our narrative is correct and the narrative of our masters is wrong? We know what would be 
the next stage. They could easily find professional historians who would do the opposite, namely who would say: "We have researched properly. In fact we have had better access because we have better connections with the government, so have also seen some declassified material which our more antagonistic colleagues cannot see, so this is really the complete picture”.

I think there's some modesty and humility, and some very productive sense in telling the public that things are not very clear and, indeed, that things are still very unclear in many ways. The fact that we are part of an ongoing conflict and that as educated people we are also very deeply involved in that conflict, not just as historians but also as academics and intellectuals, means that indeed there is an interaction between our ideological world and the final product of our historiographical research. Although my colleagues in the joint Israeli-Palestinian effort to reconstruct a narrative at first very much objected to my more relativist point of view (mistaking it, by the way, for a postmodernist kind of approach where 'everything goes'), I think as the years went by, and we've already been meeting for almost for a decade, they understand that this was really necessary for incrementally building a trust between historians and their societies about the past. I'm willing to say something more about it if there is time but I think the relativist approach is the first precondition. I shall call it the 'soft' relativist approach. I realise that this is not the best term, but those of you who are familiar with the historiographical debate over the late 50 years would understand what I mean by that.

The second necessary precondition for building a joint narrative is, of course, a great belief in the role of history in conflicts. In other words, historians suddenly find themselves, not sidelined but, contrary to their wishes, very much in the centre of the political debate. In the case of Israel and Palestine, this is very obvious. The question of whether or not an ethnic cleansing took place in 1948 is crucial for the future debate about the solution for the Palestinian refugee problem. This is a purely historical question to begin with - the question of responsibility, the question of defining the historical event and finding the political implication. Now if the Israeli point of view is accepted, there was no ethnic cleansing, hence there is no Israeli responsibility hence there is no need to deal with the refugee problem as part of the conflict. From the Palestinian point of view, there was an ethnic cleansing and therefore there is an Israeli responsibility and therefore future negotiations of peace and reconciliation in Palestine should focus on the issue of refugees. 
It was very interesting to see how the negotiators during the Oslo accord in 1993, on both sides, used history for advancing their cause. In the beginning of the Oslo negotiations, the Palestinian negotiators were very suspicious about the willingness of the Israeli side really to deal with the issue of the refugees. So the Israeli negotiators, in fact the chief negotiator at the time, Yossi Beilin, produced my book and others to show the Palestinian negotiators that indeed there is new thinking in Israel about the refugee issue. He said, "There you are, you see we have historians who talk about ethnic cleansing, we're definitely going to respect your point of view." In the summer of 2000, when the Israeli negotiating position had totally changed and they told the Palestinians that the refugee issue was not a issue, it was the Palestinian negotiators who produced our books and said, "But don't you understand, there are historians in your society who have already recognised that what happened in Palestine in 1948 was an ethnic cleansing operation.” So history is used and abused by politicians and historians should be aware that they are part of the political debate as much as they part of the intellectual debate.

The third guideline or condition that really emerged out of the dialogue, the very constructive dialogue that we still have between Israeli and Palestinian historians, is that if we - speaking simplistically — distance ourselves from elite politics and elite history, by adopting a quite cynical, even negative attitude towards politicians on both sides as people who made history and who affect history, then the non-elite history is much easier to produce as a joint project. It is the political elites' histories which are very difficult to bridge between. We found this in the case of Palestine particularly in the case of the history of workers and of women. These two fields are relatively easily reconstructed jointly and once they are liberated from the national narrative of both sides which totally excluded them, neglected them and in fact victimised them as far as an historical narrative can victimise people, when compared to actual victimisation of course. And when we started working together on the history of the movements of workers in Palestine we found out that both national leaderships, the Palestinian and the Jewish, had made every effort to undermine any attempt by Arab and Jewish workers to unite on the basis of class consciousness or class solidarity, and to question the need to unite on the basis of a national or ethnic or religious base. I think that this by itself was not just an important highlighting of a very dark area or lacuna in the historiography of both sides, it was also a very important message for the future, about groups that do not 
belong to the political elites and how they fare. Because national narratives, national interpretations of reality, not only in the past, but also in the present, dominate our life. The same was true about feminist historiography, which is very limited in both cases. In fact it was through the attempts to bridge a building narrative that that kind of historiography found a much easier way of getting into the main domain of historiography. I think this was particularly true about the Palestinian side where the best that feminist historiography could produce at the time was finding out how much women on the one hand contribute to the national effort and how much this effort was not recognised once the national struggle came to a halt or to a lull. I think it was through the bridging narrative effort that it was possible to widen the scope of the historical research into the dialectical relationship between nationalism and women's rights and histories. This again is not just a matter of an intellectual curiosity about what happened in the past, it is of course far more important as a way of understanding what is ahead of us in the future, something which positivist historians find very alarming when you tell them that their works really should take that into account.

Fourthly, we dealt - and again there was a lot of opposition-with the impact of modernisation theories on historiography, not only in the case of Israel and Palestine but, I think, in the case of historiographies in the decolonised world altogether. The obvious point of view which we all share, and that was the easy one, is that you have to liberate the historiography of Palestine from modernisationist theories because it supports one of the side story and totally negates the other side of the story, in other words because Zionism was part of the West and part of the colonialist world it was very clear that if you are loyal to modernisationist theories that see the West as the source of all change, of all progress, then of course you immediately side with a Zionist historiography of Palestine, even without being a practising historian. That is to say, even if you are toddler in a kindergarten and you understand basically that the West is a superior moral and intellectual force in the world, it's very clear to you that you belong as a Jew to the right camp. Of course if you are a historian, which is a bit better than a toddler, then of course you can even thicken this narrative with details and convincing arguments. Far more difficult for the Palestinian historians was to realise that they are as much enslaved by modernisationist theories as were we, the Israeli historians. Because nationalism, anti-colonialist nationalism, is also part of the modernisation theories. In fact it is an integral part of a modernisationist westernised historiography to predict that after civilisation or after civilised enlightened ideas are brought from the 
outside into the inside, these would be the only reason for the dynamics of change and development. This means that a very successful westernisation of local non-westernised society is that the primitive people would realise what nationalism is all about and of course would want to be civilised themselves and therefore rebel against the domination of the foreign colonialist movement. Hence, the whole idea that Palestine could only be liberated if an elite, a political elite in Palestine could adopt western concepts of civilisation, politics, and morality as the way forward, was no less problematic that the idea of the Zionist elite that the best thing for the Palestinian was to be led towards modernity and enlightenment by the Zionists themselves, being the bearers of the message of modernisation.

Now in order to push forward this idea, that you don't only have to liberate your historiographies from the national domination to de-nationalise your historiography, you have to de-modernise it in many ways, one had to convince oneself, and our Palestinian partners - indeed this was the enabling move - to widen the group of people who joined us in the effort to build a bridging narrative. We found out that historians who were closer to the Islamic movement in Palestine were willing to join the effort once we were talking in such terms. Because what does it mean? It means that you do not regard, as you do in modernisationist theories, that the past itself or tradition and religion are barriers for development, or are the human concepts that do not allow societies to thrive, or be enlightened, which is something which was common both to the Palestinian national historiography and the Israeli nationalist historiography. They both regarded the past as an inflexible time that it was much better for the people on both sides to get rid of. They regarded tradition and religion as two interpretations of realities that would not allow people to move forward. And of course as those of you who are familiar with the varieties of feminist historiography on the Middle East would realise, these concepts have been re-evaluated. It is not a coincidence that at the same date there were two very big and apparently contradictory demonstrations held. There was a big mass demonstration in Ankara by women demanding of the Turkish government that it allow women to wear the veil in Turkish universities as a sign of self-identity and respect against an oppressive Turkish government. And on the same date there was a demonstration in Iran by women demanding the right to remove the veil with the same kind of agenda. And this kind of interaction is very important if we want to widen the scope of the historiographical project. The de-modernisationist approach, so to speak, enabled us to look at internal factors, internal forces in Palestine, 
in what probably would be defined by western historians as a pre-modern era, as being the forces of change, the forces of development, the forces that maybe did not move as fast as the westernised forces wanted them to move, but moved at a much more adequate pace with regard to the society around them.

And I would like to conclude by saying that the fifth and last precondition was much more concrete and maybe much methodological, in a way, but I think it has also wider implications. This dealt with the hierarchy of sources. It was very clear that if you adopt a modernisationist point of view, a nationalist point of view, an elitist point of view (which were all the kinds of points of view we were trying to challenge), you are a great believer in the written document. You deal only with relics which are left behind by the political elite. They leave behind them mountains of papers. Anyone who has been in the public records office can see the glimmer in the eyes of the historians when they leave the cafeteria to move into the shrine of truth, which is the British Public Record Office. This is of course full of documents written by British diplomats who kept lying about the truth, but never mind, there is a lustre of truth in this shrine, like in any national archive I would think. They would know that it is a very accessible source for reconstructing history, especially if we're talking about graduates from Oxford and Cambridge who have a very articulate way, even already in the 1920s, to write about that reality. So all you have to do as an historian is just to use it, to find some connecting sentences and you have a very lucid description of the reality. But of course this was NOT the reality, this was a British diplomat sitting somewhere in the Middle East, having all the prejudices in the world to direct him, while he was producing a certain survey of the reality. The same is true about many of the political assessments and surveys that we have of the past. And it's quite interesting, in fact quite intriguing, how historians would, probably rightly, be very suspicious about contemporary politicians when they describe to them the reality around them. But if there is a thick, or even a thin layer of dust over a politician's assessment from 50 years ago, it suddenly becomes an authentic and objective description of reality - but of course only if it fits the historian's point of view, consciously or unconsciously. So the written document becomes the only and exclusive way of describing reality because it is the elites' point of view. And in fact the elites were educated enough to leave the evidence behind them for contemporary modern historians. 
But if we go into a more expansive area of history, then we have a very different point of view. I'm sure you're all familiar with how the kit of the historian has changed in the last 100 years thanks to such schools of thought as the Annales in France. Other interactions between historians and social scientists, have produced multiple ways of reconstructing the past. You don’t only need written documents, you need these as well as other means if you are interested in finding out about a much more complex history, the history of the non-elite groups. And that is not as definite and it isn't taken as being as definite as the history of politics or the history of politicians. And almost in the last moment, and with this I will end, because of our agreement as a group of historians, we dealt with oral history, putting oral history on the same pedestal as written history or written documents, and thus succeeded in enlightening ourselves and hopefully also the people who would read our work, about 1948. Because one of the major obstacles for moving on with the joint narrative, or the bridging narrative project, was the fact that the Israeli historians felt rightly that to talk about ethnic cleansing in Palestine was not the full picture of what happened in 1948. Because in 1948 the State of Israel came into being and in 1948 there were some heroic stories about how Jews in isolated settlement defended themselves against large Arab armies. The question was, how can it be that an ethnic cleansing operation can sit comfortably together with a story of national independence?

What the oral history enabled us to do was to find out that in fact even in a small country like Palestine in 1948, the concept of war is very misleading. Only in certain geographical areas did you have a proper war, one small army confronting another small army, the Egyptian army versus the Israeli army, the Syrian army versus the Israeli army, but this was limited to certain areas. In fact in the rest of the country, there were not two armies clashing with each other, there was a military force, the Israeli military force operating within a non-military environment. We started using known concepts and definitions of ethnic cleansing like the ones which are provided by the State department and United Nations and it fitted very well into what the Israeli army was doing in between the beginning of 1948 and the end of 1948, within the Palestine territories. I think the very fact that the Palestinian historians were willing to say that apart from the ethnic cleansing other things were happening as well and the fact that the Jewish historians were willing to say that apart from what they thought was happening in terms of the building of a new society, an ethnic cleansing operation also happened, that the one did not exclude the other. This assessment was only possible through oral 
history, and why is that? Because the Israeli archives have never revealed the full extent of the ethnic cleansing. The Palestinians are keeping the archives of memory through successive generations of Palestinians. That's what's amazing about archives of memory, they can be taken to a generation that has not lived through that period. The archives of memory completed the picture. I think that humanising the stories on the one hand, and showing how limited the political and military archives were on the other hand, really created the constructive work that we're doing now.

To sum up I would say that the tasks facing historians who want to challenge, or need to challenge, dominating narratives are far beyond the question of finding new evidence that someone else didn't know about, or directing the spotlight onto evidence that other people do not want to face. This is definitely part of the task ahead. But I think no less important is something that historians would probably find sometimes more difficult to digest, and that is the need to have a much more interdisciplinary approach to what history is all about, a better understanding of the various disciplines to deal with the human sciences and the interpretation of reality. In the process this means losing some of the scientific and objective air that accompanied the work of historians in such societies. We would become instead much more like parliamentarians who represent different points of view than like the priest who represents the only existing truth.

Dr Ilan Pappe is a senior lecturer in the School of Political Sciences at Haifa University. His most recent book is A History of Modern Palestine: One Land Two People (Cambridge ; Port Melbourne : Cambridge University Press, 2004.) 